\title{
HUMAN RESOURCES DEVELOPMENT IN THE FUNCTION OF SUSTAINABLE DEVELOPMENT WITH REFERENCE TO THE EDUCATIONAL SYSTEM IN KOSOVSKO POMORAVLJE DISTRICT
}

\author{
Nenad Kojić́ ${ }^{1}$, Maja Staletović ${ }^{2}$, Milan Dajićc ${ }^{3}$ \\ ${ }^{1}$ College of Economics of Vocational Studies Pec in Leposavic \\ ${ }^{2}$ Business College of Applied Studies "Prof. Radomir Bojkovic, PhD", Krusevac \\ ${ }^{3}$ Technical school, Vrbovac
}

Corresponding: nenad.kojic@pr.ac.rs

Review article

Received: 12.10.2020; Accepted: 03.12.2020

\begin{abstract}
In a knowledge-based economy, the sustainable development of each country almost exclusively depends on the quality of human resources. In such conditions, the need for development is becoming increasingly important. As education becomes the most important pillar in the development of human resources, it is essential that it is in accordance with the concept of sustainable development and that it has practical value as well. The quality of education depends on the quality of the teaching staff. The development of teachers in accordance with the new trends which are imposed by a dynamic environment has a major influence not only on the developments of schools but also on increasing the quality of the entire educational system, which will ultimately have a positive impact on the sustainable development of the entire economy. Consequently, a need for continuous learning and improving the necessary skills, in accordance with the demands of the environment is imposed, as we should not neglect the fact that the social development of human resources is an important component of sustainable development.
\end{abstract}

Keywords: Human resources, sustainable development, education, teacher, knowledge, changes

\section{Introduction}

A new knowledge-based era has radically changed the role and position of human resources in the working process. Dynamic changes, from new technology to the need for acknowledging social communities 
Kojić N. et al., Human reosurces development in the function of sustainable development

and rules regarding environmental protection, have become a powerful factor imposing the need for their development. Since education has an impact on the development of human resources through the acquisition of new knowledge, skills, and desired abilities, it is necessary to make certain changes in that segment as well. The education reform implies a continuous professional development of the teaching staff as the bearer of the educational system. The subject of the research is to point out the need for continuous development of human resources with special references on the development of human resources in the educational system, because they, in contemporary management conditions, are faced with major challenges within their teaching profession. Due to all the changes and innovations in the educational system, the goal is to point out the attitudes of teachers in schools in Kosovsko Pomoravlje based on research, regarding the quality of our education, further advancement, and implementing new trends into the educational system, but also regarding the importance of responsible behavior. This paper has the following starting hypothesis: The need for implementing new trends (such as digitalization, dual education, life-long advancement, social responsibility) into the education system has recently been recognized by a large number of teachers. For the purposes of this research, we have compiled a survey containing 16 questions. The research has been done on a sample of 50 teachers in four high-schools and two elementary schools in Kosovsko Pomoravlje. The obtained results were processed in accordance with certain methods of descriptive statistics, they were presented numerically, graphically and qualitatively described. In the beginning of this paper, we indicate the need for the development of human resources in the function of sustainable development, as well as the dire need for the professional development of human resources in the education system of Serbia. After that, the results were presented and analyzed.

\section{The need for the development of human resources in the function of sustainable development}

In contemporary management conditions, when organizations are faced with dynamic changes in economic, ecological, and even in the social segment, the need for the development of human resources is becoming increasingly important. Thanks to the existence of creativity and readiness to do business in accordance with the rules of sustainable development, each organi- 
zation will be able to respond to the challenges they are facing in such conditions. Creating an environment that will encourage the development of the staff and at the same time ensuring that everybody has equal opportunities to access developmental programs, present the activities and mechanisms that each modern organization has to establish. [Radosavac, 2016, 161176] Sustainable development of each modern organization, regardless of what activity it is engaged in, is based on the exploitation of intellectual abilities of human resources. People are becoming an important factor of economic [Stanojevic, 2015] but also sustainable development. Regardless of all contemporary achievements in the sphere of robotics and technology, they are still an irreplaceable part of the functioning of modern economies. [Zakic, 2018] It is for this reason that they have great importance nowadays. Without the development of an adequately formulated strategy which will contribute to the creation of highquality, educated, and productive individuals, it is hard to make progress in society.

Education and abilities as individual characteristics of each individual that cannot simply be copied are precisely what contributes to sustainable development. For this reason, adequate management of the development of human resources becomes imperative for each organization. Hence the need for the development of human resources in the new economy. The benefits are numerous, in addition to the productivity at work increased, the employees are motivated and satisfied, the companies gain competitiveness, they become productive and are, therefore, readier to face the demands of the environment, which creates preconditions for their more successful and rational business management in accordance with the dimensions of sustainability. As the acquisition of knowledge, creative skills, and other necessary abilities becomes a long-term process in which the companies invest a lot of financial resources, the human resources development requires a complex approach and long-term planning. [Kazakovs et al., 2015] Unlike the traditional economy, in the knowledge-based economy, the development of human resources is approached somewhat differently. In the era of the knowledge-based economy, continuous training with the aim of adapting already existing and acquiring new knowledge and skills necessary for the realization of personal and common goal on the level of the organizational system should follow technicaltechnological progress, but also the demands that environment and 
Kojić N. et al., Human reosurces development in the function of sustainable development

social community impose. Strong technical-technological progress as a feature of the contemporary economy, brings dynamics in the development of human resources, and affects the change of their position in the work process. The more and more perfect technique and technology, the need for the development of innovation, research, and development, are pushing down the existing professions day by day, demanding the emergence of new ones. There is an increasing demand for IT experts and informatic economy, analysts of environmental protection, but also for numerous providers of intellectual services, such as scientists, professors, etc. [Jovanovic, 2017] The degradation of the environment and the public's interest for every organization to behave socially responsible set new rules which should be acknowledged in the development of human resources. Such conditions impose the need for routine work, based on already acquired knowledge to be surpassed because such knowledge is no longer sufficient for the normal functioning of any modern organizational system. As education becomes the key instrument for reaching the goals of sustainable development (Regional environmental center,) the educational system must undergo certain changes. It is necessary that people become able to adequately react to the existing and possible future changes, through formal but also informal educational system. It is vital that today the process of human resources development continues to develop in accordance with the concept of sustainability as well. This also applies to human resources in educational institutions.

\section{Professional development of human resources in the Serbian educational system}

In a knowledge-based economy, education becomes the most important part of the social development of human resources. [Bilinović \& Škorić, 2015] Without high-quality education, there can neither be high-quality knowledge, nor the advancement of the society as a whole. [Sucevic \& Keric, 2015] It is possible to provide adequate education only thanks to high-quality teaching staff. Education in Serbia can significantly contribute to sustainable development if by using certain mechanisms for the improvement of the quality of human resources it ensures the possibility of acquiring permanent and useful knowledge. In this way, the quality of teaching will be improved, but also the position of the teaching profession in society as well. In this 
sense, there is more and more talk about the need for the professional development of teachers [Tancic et al. 2017; Gosovic \& Perović, 2016; Becirovic, 2015] which, in relation to professional development can have a greater contribution to the sustainable development of our country. More complex demands for teachers today imply a much greater involvement rather than in the traditionally organized teaching, both in terms of organization and performance of the teaching process, encouraging pupils to be active, monitoring, and evaluating their work. [Todorovic, 2019] Teachers are expected to be a good motivator and connoisseur of different methods with a goal of organizing the lessons in a significantly more flexible way that will enable a more intensive involvement of pupils in the work, through the process of interactive teaching. Modern education is, among other things, based on digital competencies, so a teacher is required to possess knowledge and skills for a high-quality usage of information and communication technologies. As previously shown, in relation to the traditional economy, the roles of teachers have significantly changed in the knowledge-based economy. [Pozar, 2016] which imposes a need for permanent professional improvement and learning throughout the whole life. It can be said that the possibility for education to become one of the most important factors which will contribute to the sustainable development of the Serbian economy depends on individual characteristics of teachers, their competence, and readiness to accept the methods of modern education.

In this situation, the support of the state should not be ignored, which is indispensable, in terms of help when it comes to financial $\mathrm{re}^{-}$ sources, and through the adoption of imperative legal norms and strategies, as well, which will regulate this area more. [Pavlovic \& Stamenkovic, 2018]

\section{The results of research adn discussions}

In the knowledge-based economy era, the teacher becomes one of the most important drivers of the entire process of education. That is why development is expected from them, in accordance with new trends which are imposed by the changing environment, but also by the constant effort with a goal to improve the educational system. Motivated with this fact we have conducted research which, among other things shows the attitudes of teachers regarding the implementation of new trends into the educational system and what are their opinions about the need for further 
Kojić N. et al., Human reosurces development in the function of sustainable development

improvement and studying. For the purposes of this research, we have compiled a survey containing 16 questions, through which we investigated the following aspects: the attitudes of teachers regarding the core goal of education, the satisfaction with the quality of our educational system, whether the quality of education is an important issue in our country, attitudes regarding what should be changed in Serbian educational system and about the need for implementation of new trends into the educational system, their priority, digitalization, education, intentions for further improvement, as well as the opinion about the importance of the educational system for achieving the social-economic growth. The $\mathrm{re}^{-}$ search was conducted in February 2020 , on the model of 50 respondents in elementary and highschools in certain places in Kosovsko Pomoravlje (Vitina, Vrbovac, Parteš, Šilovo, Pasjane). The respondents were divided in categories according to the type of school they worked in.

Table 1. Distribution of respondents according to the school type

\begin{tabular}{|l|l|c||}
\hline \multicolumn{1}{|c|}{ School } & \multicolumn{1}{|c||}{ Type of school } & $\begin{array}{c}\text { Number of } \\
\text { respondents }\end{array}$ \\
\hline \hline Medical School & secondary-professional & 11 \\
\hline Economic and trade school & secondary-professional & 5 \\
\hline Technical school & secondary-professional & 10 \\
\hline High school & high school & 9 \\
\hline Elementary school "Mladen Markovic" & primary school & 9 \\
\hline Elementary school "Marko Rajkovic" & primary school & 6 \\
\hline \hline In total & 50 \\
\hline
\end{tabular}

The research has shown that in the given sample there were 20 male teachers and 30 female teachers. The average age of all respondents is 42.88 years. Average age of male respondents is 43.80 years, and the average age of female respondents is 42.26 years (Table 2 ).

Table 2. The average age of respondents based on the gender

\begin{tabular}{|l|r|r|r||}
\hline \multicolumn{1}{|c|}{ Gender } & Average & \multicolumn{1}{c|}{ MIN } & \multicolumn{1}{c|}{ MAX } \\
\hline \hline Male & 43,80 & 27 & 27 \\
\hline Female & 42,26 & 61 & 63 \\
\hline In total & 42,88 & 27 & 63 \\
\hline
\end{tabular}


According to the level of education, a total of 33 respondents had a master's degree, 10 of the respondents had specialists' studies and a total of 7 respondents have completed basic studies. None of the respondents had finished doctoral studies.

On the sample of 50 respondents, $46 \%$ believes that acquisition of high-quality education should be the main goal of our educational system, whereas only $6 \%$ of the respondents think that the main goal of education should be the development of creativity and personal talents (graph 1), which represents one of the significant competencies which human resources should have nowadays.

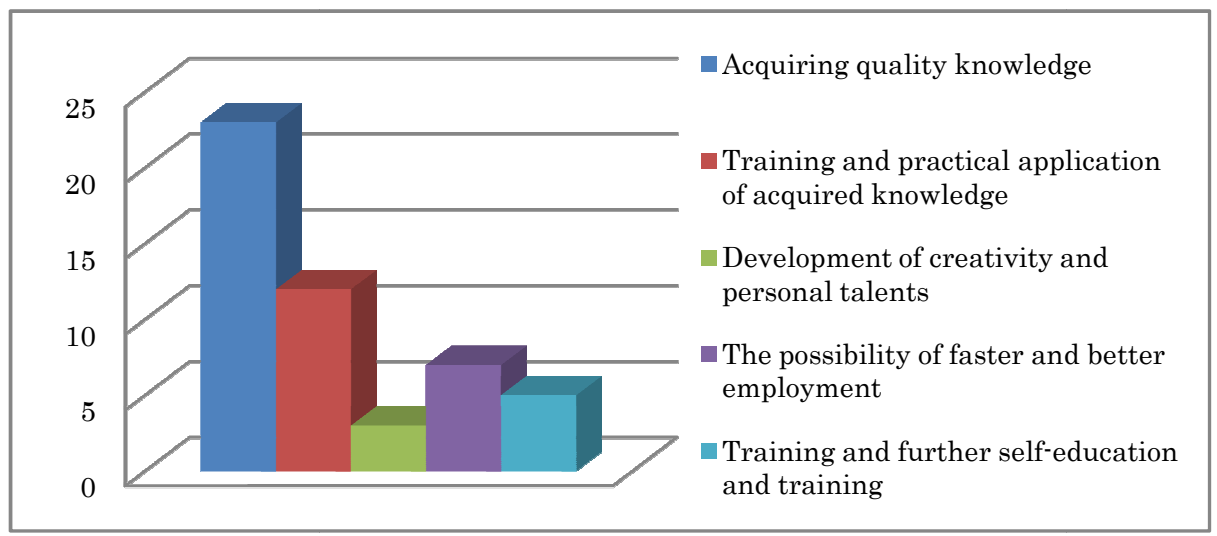

Graph 1. The attitudes of respondents regarding the main goal of education

The results show that most of the respondents, 33 in total, is quite satisfied with the quality of our educational system (graph 2). According to the document which defines the strategic goal of educational development in the period between 2010 and 2020, the educational system of Serbia is facing major issues. [National Education Council, 2020] According to the results of our research, $36 \%$ of respondents believes that the edu- cation is an important issue that Serbia is facing today, but not to a great extent (graph 3). Improving the education system can be achieved through the increased quality of education and strengthening of the connection between educational institutions, research centers, and the economy [Knezevic \& Veselinovic, 2015], but it can also be achieved through investment in the development of the teaching staff. 
Kojić N. et al., Human reosurces development in the function of sustainable development

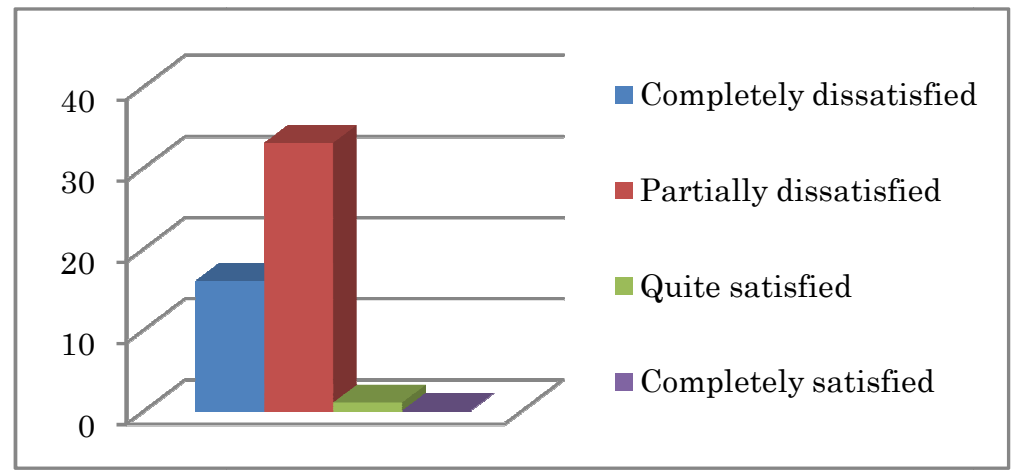

Graph 2. The level of satisfaction of the respondents with the quality of education

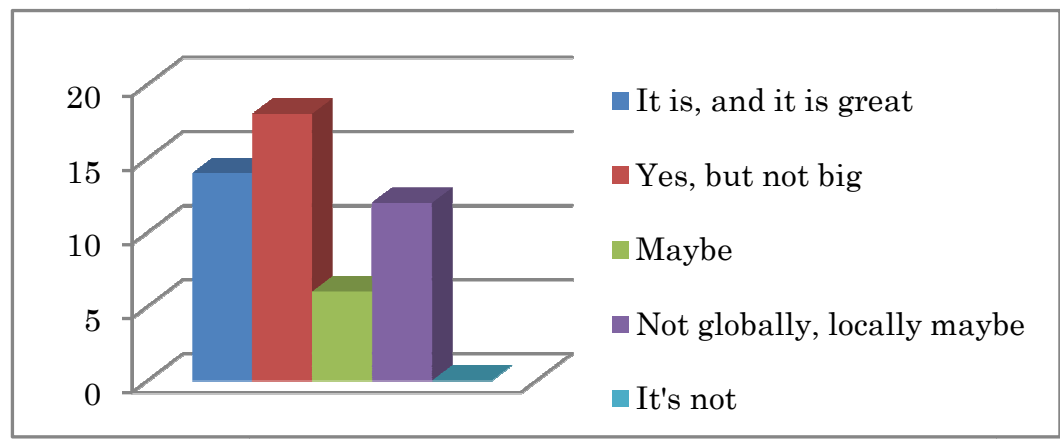

Graph 3. The attitudes of the respondents regarding the question whether the quality of education is the main issue that Serbia is facing in modern conditions.

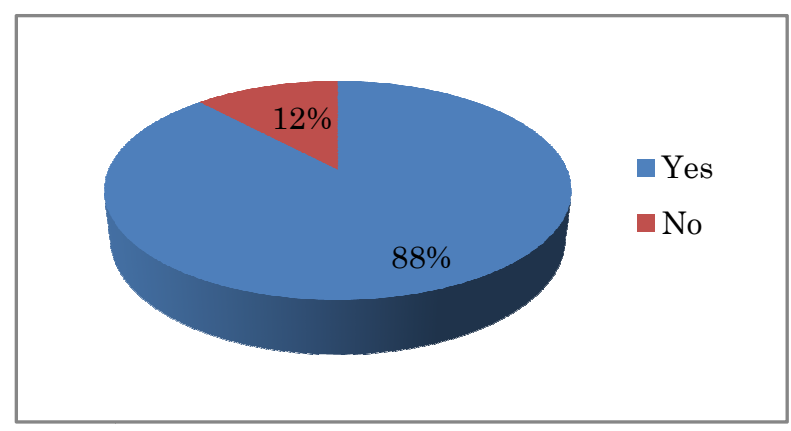

Graph 4. The attitudes of the respondents regarding the need for implementation of new trends in the educational system 
In the given sample, $88 \%$ of the respondents pointed out the need for implementation of new trends in our educational system (graph 4).

In an economy based on knowledge, innovation is the most important source of change. [Dajić, 2017) The teachers of Kosovsko Pomoravlje give the priority to digitalization and dual education in this matter (graph 5). Within digital competencies, the Ministry of Education, science, and technological development recognized the importance of digital technologies for improving the educational system. [Digital Competence Framework, 2020] Digitization and the digital economy can be considered to be the greatest phenomena of the $21^{\text {st }}$ century. [Jankovic et al., 2019]

Martín-Gutiérrez and his associates talk about the importance of the application of virtual technology in education. [Martín-Gutiérrez et al., 2017] The application of multimedia becomes an imperative of modern teaching. [Vrhovac et al., 2017] According to our research, $96 \%$ of the respondents believe that the digitalization of the educational system is very important.

However, in Kosovsko Pomoravlje district, there is only a certain number of schools that are equipped in accordance with the $21^{\text {st }}$ century standards. This is the case with the elementary school "Desanka Maksimovic" and grammar school in Kosovska Kamenica which has been using digital textbooks since 2018/2019. The usage of digital textbooks imposes the need for the development of com- $^{-}$ puter skills of teachers which further requires additional training and knowledge for which $42 \%$ of the respondents are interested, whereas $28 \%$ of the respondents in the district of Kosovsko Pomoravlje said that they are not thinking about the need for further training.

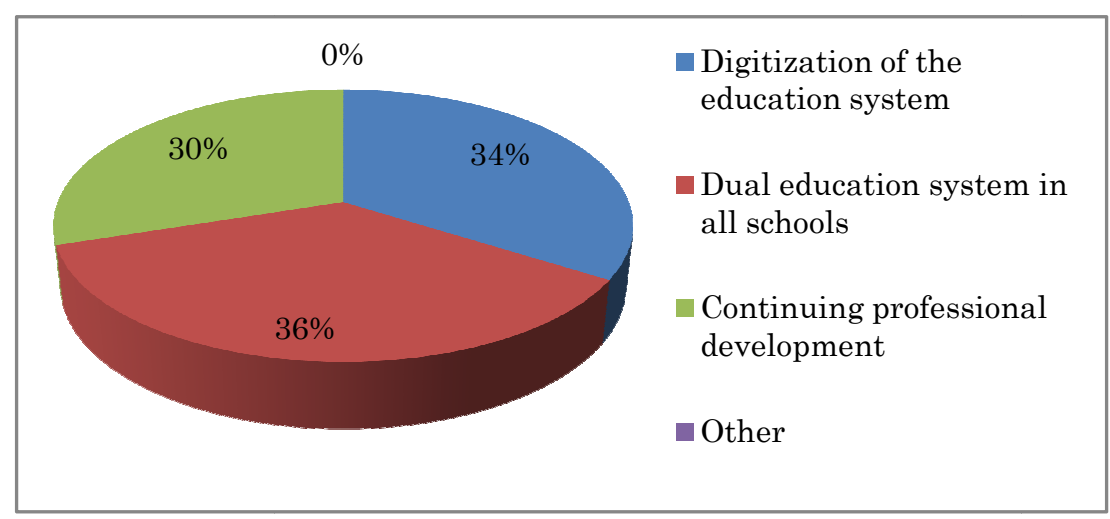

Graph 5. Respondents' attitudes about the priorities of introducing new trends 
Kojić N. et al., Human reosurces development in the function of sustainable development

Education is a key determinant of sustainable development of every economy [Gavrilovic \& Radivojevic, 2017] which our research also suggests, as $62 \%$ of the respondents believe that a high-quality education is a basis for achieving sus $^{-}$ tainable social-economic prosperity of Serbian economy (graph 6).

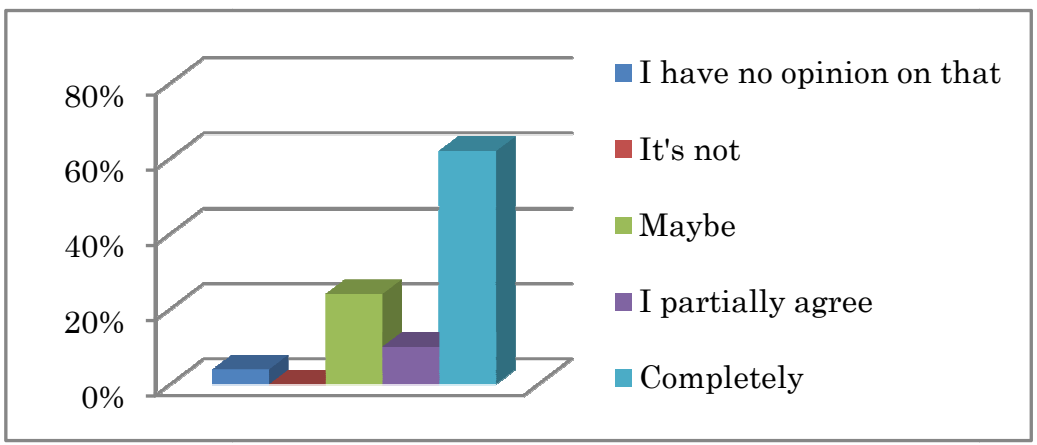

Graph 6. The attitudes of the respondents about whether a high-quality education is a basis for achieving sustainable development of a country

When asked what they would Sustainabilility is the future surchange in the educational system of Serbia, $34 \%$ of the respondents agree that it is necessary to coordinate the educational system with the needs of the market, whereas $30 \%$ thinks that it is necessary to emphasize not only theoretical but also practical knowledge (graph 7). However, schools in the area of Kosovsko Pomoravlje are facing the issue of insufficient interest of Serbian businessman for the pracvival of the Earth but also all its inhabitants. [Ilic et al., 2019] Education is a key determinant of sustainable development of every economy. [Gavrilovic \& Radivojevic, 2017] which our research also suggests, as $62 \%$ of the respondents believe that a high-quality education is a basis for achieving sustainable social-economic prosperity of Serbian economy (graph 8). tical work of students. 


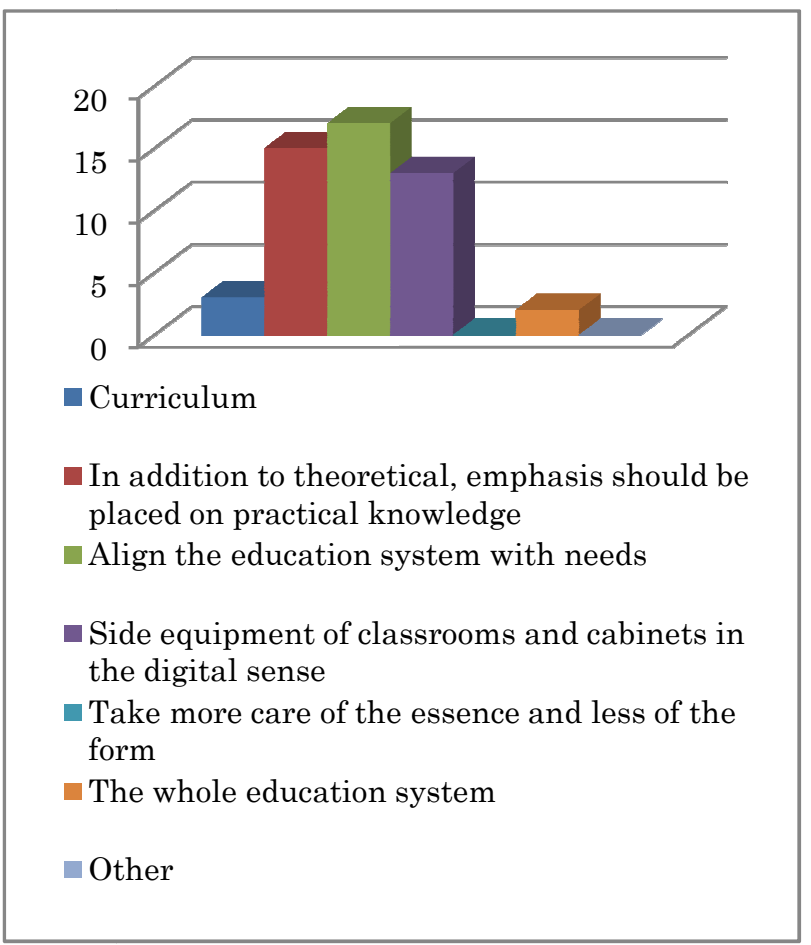

Graph 7. The attitudes of the respondents regarding the changes in the Serbian educational system

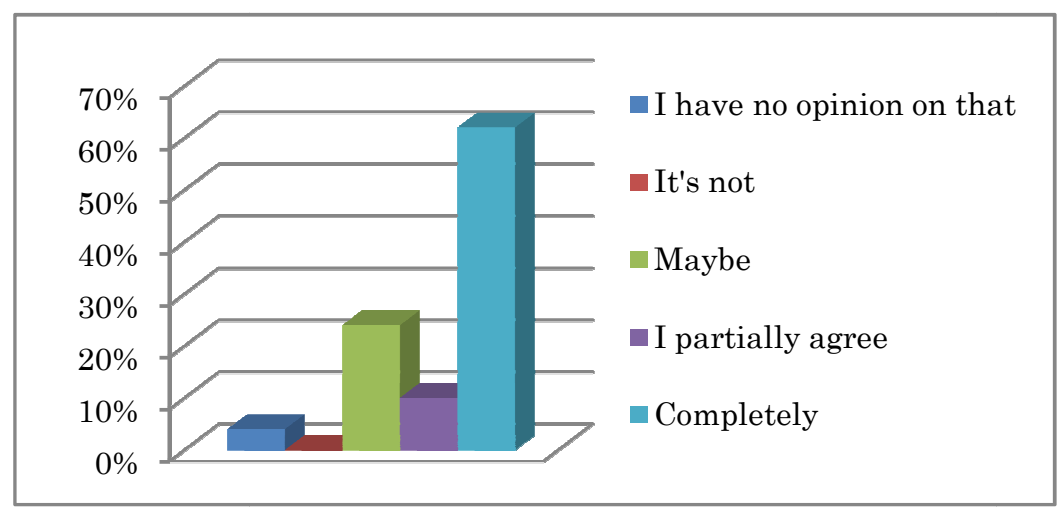

Graph 8. The attitudes of the respondents about whether a high-quality education is a basis for achieving sustainable development of a country 
Kojić N. et al., Human reosurces development in the function of sustainable development

There is a weak connection be- the same opinion that our educatween the educational system and tional system is only partially the labor market in Serbia. [Obra- (graph 9) in accordance with the dovic et al.] Our respondents have needs of the economy.

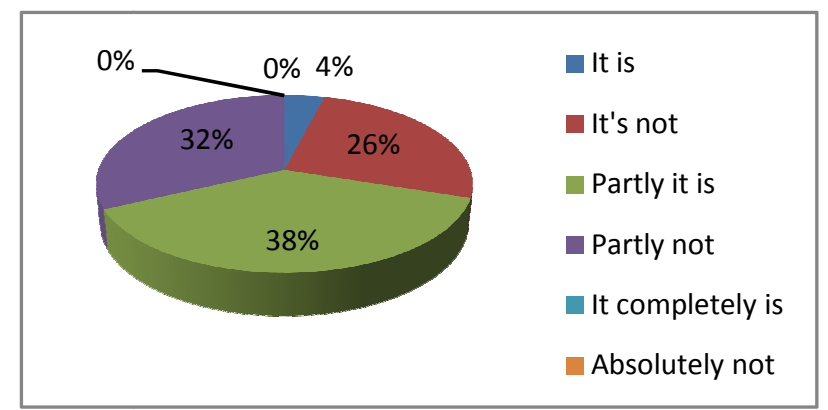

Graph 9. The attitudes of the respondents about whether the Serbian educational system is in accordance with the needs of economy

At the end of the survey, respondents were given the opportunity to write something about the education, however, only a few of them answered that mostly everything was covered through the survey questions above.

\section{Conclusion}

It can be concluded that, unlike traditional, in a weightless economy the development of human resources in the function of sustainable development becomes of strategic importance. Having in mind that education is the most important segment of the development of human resources and that teachers are the main bearers of the proper functioning of the entire educational system, a need for the development of the teaching staff has emerged. Successful countries around the world are spending more and more resources on the continuous training of the employees in educational systems in accordance with the new trends, which our country should do as well. Continuous development of human resources in educational facilities actually implies the readiness of the teachers to adopt a vision of lifelong education, learning and acquiring digital competencies, and that through one`s own continuous development in a highquality and efficient manner $\mathrm{re}^{-}$ spond to new trends implemented into the educational system 


\section{References}

Becirovic, S., (2015). The impact of social change on the role and reponsibility of teachers in modern educational systems. New Muallim, (62), 114-121.

Bilinović, A. \& Škorić, J., (2015). Education as a factor of social development. Regions and $R^{-}$ gionalization: A Comparative Analysis IV, Novi Sad, Faculty of Philosophy, 43-62.

Dajić, M., (2017) Uloga i značaj inovacija u razvoju privrede Srbije, Ekonomski signali, 12(1), 69-78.

Gavrilovic, B.J. \& Radivojevic B., (2017). Educating the population for the future and the future of education, Population, 55(1), 6385.

Gosovic, R. \& Petrovic, D.S., (2016). Standards for the teaching profession and their professional development. Intercultural education in Serbia - regulatory framework, situation and opportunities for development, Belgrade, Center for Educational Policies, 71-75.

Ilic, B., Sovtic, K. \& Mihajlovic, D., (2019). Economic and ecological sustainability of Serbia/condition of quality of life and environment protection, Ecologica, 26(94), 193-198.
Jankovic, M., Jovanovic, L., Gajdobranski, A. \& Jovic-Bogdanovic, A., (2019). The role of digital economy in protecting the environment and ecosystem from natural disasters, Ecologica, 26 (94), 153-158.

Jovanovic, B., (2017). New information technologies in economics. Scientific conference ECONBIZ (17), 359-366.

Kazakovs, M., Verdina, A. \& Arhipova, I., (2015). Automation of human resources development planning, Procedia Computer Science, 77, 234-239.

Knezevic M. \& Veselinovic, P., (2015). New Education Policy's Priorities as a Function of Economic Development of Serbia, Economics, 61 (1), 151-159.

Martín-Gutiérrez, J., Mora, C.E., Añorbe-Díaz, B. \& GonzálezMarrero, A., (2017). Virtual technologies trends in education. EURASIA Journal of Mathematics Science and Technology Education, 13(2), 469-486.

National Education Council, (2020) Education in Serbia to achieve better results, WwW.cipcentar.org

Digital Competence Framework (2020) Teacher for the Digital Age 2019, www.zuov.gov.rs 
Kojić N. et al., Human reosurces development in the function of sustainable development

Obradovic, J., Arsic, S. \& Veljkovic, M., Serbian labor market as a mirror of (in) harmonization of the education system and the real needs of the economy, University in change, $X X I$ conference Development trends, Zlatibor, 1-4.

Pavlovic, R. \& Stamenkovic, S., (2018). Investing in human capital - a determinant of business success of organizations, MEGABIZNIS, 2/1, 25-38.

Pozar, H., (2016). Competences of teachers in modern education. SYNTHESIS, (10), 23-34.

Radosavac, Z., (2016). Human resources development as a prerequisite for organizational success, Journal of Economics and Market Communications, 6(1),161-176.

Regional Center for the Environment, Education for Sustainable Development, http://documents.rec.org/

Stanojevic, D., (2015). Human resources as a factor of economic development, SVAROG, (10),285292.

Sucevic, V. \& Keric, M., (2015). Elements and indicators for identifying the quality of primary education, SYNTHESIS, (7), 19-32.

Tancic, N.D., Vukovic, L.B. \& Malcic, B.D., (2017). Professional development of teachers through the concept of horizontal learning and teacher forums, Proceedings of the Department of Pedagogy, (26), 109-121.

Todorovic, M., (2019). Ideology and position of teachers in education, International Journal Scientific Papers, 11/2, 46-50.

Vrhovac, V., Orosnjak, M., Cvetkovic, N., Zizakov, M. \& Nikolic, D., (2017). New learning technologies in higher education. XXI conference Development trends, Zlatibor,

Zakic, K., (2018). Historical overview of human resource management development in the People's Republic of China, Megatrend University, 28-34. 


\title{
RAZVOJ LJUDSKIH RESURSA U FUNKCIJI ODRŽIVOG RAZVOJA SA OSVRTOM NA OBRAZOVNI SISTEM U KOSOVSKOM POMORAVLJU
}

\author{
Nenad Kojić1 ${ }^{1}$ Maja Staletović ${ }^{2}$, Milan Dajić ${ }^{3}$ \\ ${ }^{1}$ Visoka ekonomska škola strukovnih studija Peć u Leposaviću \\ 2 Visoka poslovna škola strukovnih studija "Prof. Radomir Bojkovic, PhD", \\ Kruševac \\ ${ }^{3}$ Tehnička škola, \\ Korespondencija: nenad.kojic@pr.ac.rs \\ Rezime. U ekonomiji zasnovanoj na znanju, održivi razvoj svake zemlje skoro \\ isključivo zavisi od kvaliteta ljudskih resursa. U takvim uslovima, potreba za \\ njihovim razvojem sve više dobija na značaju. Kako obrazovanje postaje \\ najvažniji stub u razvoju ljudskih resursa, veoma je važno da bude usklađeno \\ sa konceptom održivog razvoja i da ima praktičnu vrednost. Kvalitet \\ obrazovanja zavisi od kvaliteta nastavnog kadra. Razvoj nastavnika, u skladu \\ sa novim trendovima koje nameće dinamično okruženje, ima veliki značaj ne \\ samo za razvoj škole već i za povećanje kvaliteta celokupnog obrazovnog \\ sistema, što će na kraju imati pozitivan uticaj na održivi razvoj celokupne \\ privrede. Shodno tome, nameće se potreba da se učenje i usavršavanje \\ neophodnih veština, u skladu sa zahtevima okruženja, odvija u kontinuitetu, \\ jer ne treba zanemariti činjenicu da danas socijalni razvoj ljudskih resursa \\ predstavlja važnu komponentu održivog razvoja.
}

Ključne reči: Ljudski resursi, održivi razvoj, obrazovanje, nastavnik, znanje, promene 